\title{
INHIBITION OF FOULING BACTERIA BY THE MARINE EPIPHYTES FROM SELECTED LOCATIONS IN MALAYSIA
}

\author{
Nor Afifah Supardy ${ }^{*}$, Darah Ibrahim ${ }^{1}$, Sharifah Radziah Mat Nor ${ }^{1}$, Wan Norhana Md \\ Noordin $^{2}$, Ahmad Ismail ${ }^{3}$ \\ ${ }^{1}$ Industrial Biotechnology Research Laboratory (IBRL), School of Biological Sciences, Universiti Sains \\ Malaysia, Penang, Malaysia, ${ }^{2}$ Fisheries Research Institute, Batu Maung, Penang, Malaysia, ${ }^{3}$ School of \\ Environmental and Natural Resource Sciences, Universiti Kebangsaan Malaysia, Malaysia. \\ * Corresponding author: afifahsupardy@ gmail.com Tel: +60126079265 Fax: +6046565125 \\ Received: 19 May $2016 \quad$ Revised: 24 Feb 2017 \\ Accepted: 27 Feb 2017
}

\begin{abstract}
The rising demand for natural antifouling agents has led to the search for potential secondary metabolites from marine epiphytic bacteria. The objective of this study is to isolate the epiphytic bacteria from various marine invertebrates and to screen for their antibacterial activities against a list of fouling bacteria. In this study, the antibacterial activity of 91 epiphytic bacteria were tested against 21 fouling bacteria. In the preliminary screening of the inhibition activity, the fouling bacteria were cross-streaked with the epiphytic bacteria. Isolates with prominent inhibitory activity (susceptible fouling bacteria $\geq 40 \%$ ) were subjected to fermentation for five days, and their cell-free supernatants were extracted with ethyl acetate $(1: 1 \mathrm{v} / \mathrm{v})$ to obtain the crude extracts. In the secondary screening, the extracts were tested against fouling bacteria via the disc diffusion assay. At $2.00 \mathrm{mg} / \mathrm{disc}, 12$ out of 30 extracts were effective against at least one fouling bacteria. Two most outstanding antibacterial activities were demonstrated by isolates PD4.8 and PD4.9, which were isolated from Caulerpa racemosa. Isolate PD4.8 was effective against five fouling bacteria with the largest inhibition zone of $16.0 \mathrm{~mm}$, whilst PD4.9 was effective against four fouling bacteria with the largest inhibition zone of $15.0 \mathrm{~mm}$. This study demonstrated a significant antibacterial activity of epiphytic isolates PD4.8 and PD4.9 against the fouling bacteria, and should be further investigated for production of antifouling compound.
\end{abstract}

\begin{abstract}
ABSTRAK Peningkatan permintaan terhadap agen anti-penempelan semulajadi telah membawa kepada pencarian metabolik sekunder yang berasal daripada bakteria laut. Objektif kajian ini adalah untuk memencilkan bakteria epifit daripada pelbagai invertebrata laut dan untuk menguji aktiviti antibakteria mereka terhadap bakteria penempelan. Dalam kajian ini, akitiviti anti-bakteria oleh 91 bakteria epifit yang dipencilkan daripada invertebrata laut diuji terhadap 21 bakteria penempel. Dalam pemeriksaan awal aktiviti perencatan, bakteria penempel dicoretkan bersilang dengan bakteria epifit. Pencilan dengan aktiviti perencatan yang menonjol (bakteria penempelan terkesan $\geq 40 \%$ ) diteruskan dengan proses penapain selama lima hari, dan supernatan yang bebas dari sel diekstrak dengan etil asetat (1:1 v/v) untuk mendapatkan ekstrak mentah. Dalam pemeriksaan sekunder, ekstrak mentah diuji terhadap baketeria penempel melalui asai cakera penyebaran. Pada kepekatan $2.00 \mathrm{mg} / \mathrm{ml}, 12$ daripada 30 ekstrak didapati berkesan terhadap sekurang-kurangnya satu bakteria penempel. Dua pencilan yang menunjukkan aktiviti perencatan paling ketara ialah pencilan PD4.8 dan PD4.9 yang berasal daripada Caulerpa racemosa. Pencilan PD4.8 berkesan terhadap lima bakteria penempelan dengan zon perencatan tertinggi $16.00 \mathrm{~mm}$, manakala pencilan PD4.9 berkesan terhadap empat bakteria penempel dengan zon perencatan tertinggi $15.00 \mathrm{~mm}$. Kajian ini telah mendedahkan aktiviti anti-bakteria yang ketara oleh pencilan epifit PD4.8 dan PD4.9 terhadap bakteria penempelan dan kajian harus diteruskan untuk memencilkan sebatian semulajadi dengan aktiviti anti-penempelan.
\end{abstract}




\section{INTRODUCTION}

Marine biofouling is defined as the accumulation of living organisms on submerged biotic and abiotic surfaces after a period of time (Pereira et al., 2002). The submerged surface is initially covered by the conditioning layer of proteins and polysaccharides that is rich in organic materials. Planktonic bacteria will attach to the surface and form biofilms. The mature biofilm consists of complex structures of bacteria, cyanobacteria, diatoms and flagellates (Lappin-Scott \& Costerton, 1989). The biofilm acts as stimulator and sends cues that will attract larval invertebrates of molluscs, seasquirts, barnacles and macroalgae (Dobretsov et al., 2009).

Biofouling has a significant impact on the aquaculture industry, especially in a tropical country like Malaysia. It damages the equipment through abrasion, brittleness and load increment. The fish culturists have to clean, maintain, and replace damaged nets regularly due to biofouling (Lai et al., 1993; Madin et al., 2009). It also reduces water flow, preventing proper oxygen and waste exchange, and initiates injuries and diseases to fish. Enteromorpha sp. is one of the main culprits besides the barnacles and mussels. With sufficient light and high nutrient concentrations that are released to the surrounding waters, this 'hair algae' could extensively grow on the nets and cages (McCloskey, 2003). Their colonization on the submerged surface starts with the attachment of the zoospores and followed by the irreversible adhesion of the flagella and the growth of the thallus (Fletcher \& Callow, 1992).

The triorganotin (TBT) and copper oxide $\left(\mathrm{Cu}_{2} \mathrm{O}\right)$ coatings are commonly used in biofouling control. However, in 2008, the International Maritime Organisation (IMO) banned the use of TBT or other tin containing substances because of the toxicity effect to the non-target marine organisms. The organotin compounds tend to persist in the water, intoxicate the marine lives and bio-accumulate in the food chain (Iwata et al., 1995). Therefore, an effective and environmental-friendly antifouling agent is urgently needed to overcome this problem. Sessile marine invertebrates generally have the ability to synthesize toxic secondary metabolites as their defense mechanisms towards the predators and biofouling organisms (Bazes et al., 2006; Limna Mol et al., 2009). The prevention mechanisms are also due to the secondary metabolites produced by the epiphytic bacteria that inhabit the surfaces of the organisms and live symbiotically together (Burgess et al., 2003; Jiang et al., 
2011). In this study, we aim to investigate the antifouling property of marine epiphytic bacteria of some corals and macroalgae against a number of fouling bacteria isolated from the biofilm attached on the heavily fouled fish net from an aquaculture farm. Since the attachment of fouling bacteria is among the first steps in the process of biofouling formation, the inhibition of these bacteria could play a vital role in controlling biofouling.

\section{MATERIALS AND METHODS}

\section{Isolation of epiphytic bacteria}

Eleven samples of marine organisms were handpicked from the intertidal zones of Pulau Jerejak and Pulau Kendi, Pulau Pinang and by SCUBA diving in Port Dickson, Negeri Sembilan through the semi-thin section viewed under the microscope, and through morphological analysis. (Table 1). All samples were rinsed thoroughly with sterile artificial seawater (ASW) prepared by dissolving $40 \mathrm{~g}$ of sea salt (SigmaAldrich) in IL of distilled water $\left(\mathrm{dH}_{2} \mathrm{O}\right)$, and aseptically cut into small pieces (approx. $2 \mathrm{~cm} \times 2 \mathrm{~cm}$ ) using a sterile scalpel. The surface of the hard corals was swabbed with sterile cotton tip. The cotton tips were placed into the tube containing $150 \mathrm{~mL} \mathrm{ASW}$ and agitated at $150 \mathrm{rpm}$, $30^{\circ} \mathrm{C}$ for 24 hours. A volume of $100 \mu \mathrm{L}$ of ASW was inoculated on $50 \%$ and $100 \%$ marine agar (MA) plates (supplemented with $0.01 \%$ ketoconazole) (Devi et al., 2010). The plates were incubated at $30^{\circ} \mathrm{C}$ for 2-5 days. All individual colonies were picked and repeatedly sub-cultured on new MA plates. The epiphytic isolates were denoted as EP.

\section{Isolation of fouling bacteria}

As described by Patel et al (2003), the fouling bacteria were isolated by directly swabbing the cotton tips on the biofilm that covered the fish net from an aquaculture farm that was in close vicinity with the young Enteromorpha sp. The cotton tips were placed into the tube containing $150 \mathrm{~mL}$ sterile ASW and agitated at $150 \mathrm{rpm}, 30^{\circ} \mathrm{C}$ for 24 hours. A volume of $100 \mu \mathrm{L}$ of ASW was inoculated on $50 \%$ and $100 \%$ marine agar (MA) plates (supplemented with $0.01 \%$ ketoconazole). The plates were incubated at $30^{\circ} \mathrm{C}$ for $2-5$ days. Different individual colonies were picked and repeatedly 
Table 1. Locations and types of samples collected from Jerejak Island, Kendi Island and Port Dickson.

\begin{tabular}{|c|c|c|}
\hline Locations & Macroalgae & Corals \\
\hline $\begin{array}{l}\text { Jerejak Island } \\
\left(5^{\circ} 19^{\prime} 12.35^{\prime} \mathrm{N}, 100^{\circ} 19^{\prime} 8.11^{\prime \prime} \mathrm{E}\right)\end{array}$ & $\begin{array}{l}\text { Cladophora glomerata } \\
\text { (PJ3) } \\
\text { Acantophora spicifera (PJ5) } \\
\text { Glacilaria edulis (PJ6) }\end{array}$ & - \\
\hline $\begin{array}{l}\text { Port Dickson } \\
\left(5^{\circ} 13^{\prime} 58.51^{\prime N} \mathrm{~N}, 100^{\circ} 10^{\prime} 45.95 \mathrm{E}\right)\end{array}$ & $\begin{array}{l}\text { Sargassum sp. (PD1) } \\
\text { Caulerpa } \mathrm{sp} .(\mathrm{PD} 7) \\
\text { Caulerpa racemosa (PD4) }\end{array}$ & $\begin{array}{l}\text { Galaxea sp. (PD3) } \\
\text { Silunaria sp. (PD2) } \\
\text { Sarcophytonsp. (PD5) } \\
\text { Seriatopora hystrix } \\
\text { (PD6) }\end{array}$ \\
\hline $\begin{array}{l}\text { Kendi Island } \\
\left(2^{\circ} 32^{\prime} 11.13 \mathrm{~N}, 101^{\circ} 48 \text { '24.53 "E). }\right.\end{array}$ & - & Porites sp. (PK8) \\
\hline
\end{tabular}

sub-cultured on new MA plates. All isolates were sub-cultured on the MA slant and $15 \%$ glycerol stock and kept at $4{ }^{\circ} \mathrm{C}$ and $-20{ }^{\circ} \mathrm{C}$, respectively. The fouling bacteria were denoted as FB.

\section{Preliminary screening of epiphytics against fouling bacteria}

All EP isolates were grown overnight in $10 \mathrm{~mL}$ marine broth $(\mathrm{MB})$ at $150 \mathrm{rpm}$ and $30^{\circ} \mathrm{C}$. Each stock culture was diluted with sterile $0.9 \%$ saline solution to give about $1.5 \times 10^{8} \mathrm{cfu} / \mathrm{mL}$ (McFarland 0.5). A sterile cotton tip was dipped into the suspension and a single streak was vertically drawn at the center of the MA plate $(7.0 \mathrm{~cm}$ length; $0.5 \mathrm{~cm}$ width). The plates were incubated for 4 days at $30^{\circ} \mathrm{C}$, the FB (approx. $1.5 \times 10^{8} \mathrm{cfu} / \mathrm{mL}$ ) were perpendicularly streaked at $3.0 \mathrm{~cm}$ (length) and $0.5 \mathrm{~cm}$ (width) and $1.0 \mathrm{~cm}$ gap on the same plate. A template of this marking was drawn on a white paper and placed below the plate to facilitate the streaking (VelhroPereira \& Kamat, 2011). The plate was reincubated for another 3 days at $30^{\circ} \mathrm{C}$. Positive results were measured by the length of inhibition from the edge of the vertical streak to the closest edge of the first colony of the horizontal streak. The Test was done in duplicate. In the first replicate, EP isolates that showed greater than or equal to $50 \%$ of fouling bacterial inhibition (susceptible FB is $\geq 10$ ) wereproceeded to the second replicate. The EP isolates with inconsistence results were classified as no inhibition (Hill et al., 2009). 


\section{Fermentation and Extraction}

Firstly, the pre-culture of the selected EP was prepared by inoculating the freshly grown EP into $100 \mathrm{~mL} \mathrm{MB}$ and incubated at $150 \mathrm{rpm}, 30^{\circ} \mathrm{C}$ for 24 hours. The broth was diluted with fresh MB at an optical density $\left(\mathrm{OD}_{600}\right)$ of $0.9-1.0$ and 10 $\mathrm{mL}$ of it was transferred into $90 \mathrm{~mL} \mathrm{MB}$ and incubated at $150 \mathrm{rpm}$ at $30{ }^{\circ} \mathrm{C}$ for 5 days (Bayva et al., 2011). After five days, the cells and supernatant were separated by centrifugation at $4000 \mathrm{rpm}, 4^{\circ} \mathrm{C}$ for 30 minutes. The cell-free supernatant was extracted with ethyl acetate $(1: 1 \mathrm{v} / \mathrm{v})$ and concentrated with the rotary evaporator.

Secondary screening via disc diffusion assay

Stock cultures of freshly grown FB were prepared in sterile $0.9 \%$ saline at inoculum size of $\sim 1 \times 10^{6}$ cells $/ \mathrm{mL}$. A sterile cotton swab was dipped into the stock and uniformly swabbed onto the MA. The extracts were prepared at a concentration of $50 \mathrm{mg} / \mathrm{mL}$ in $98.5 \%$ methanol. An aliquot of $20 \mu \mathrm{L}$ of each extract was loaded onto the $6.0 \mathrm{~mm}$ sterile discs and allowed to dry (Nor Afifah et al., 2010). Copper omadine $(20 \mu \mathrm{L}$ of 0.1 $\mathrm{mg} / \mathrm{ml}$ per disc) and $98.5 \%$ methanol (20 $\mu \mathrm{L}$ per disc) were used as positive and negative controls, respectively. The discs were placed on the seeded MA and incubated at $30^{\circ} \mathrm{C}$ for 24 hours. Zones of inhibition that appeared around the discs were measured. The test was run in duplicate.

\section{RESULTS AND DISCUSSION}

\section{Isolation of epiphytic bacteria and fouling bacteria}

A total of 91 EPs and $21 \mathrm{FBs}$ were isolated from the eleven marine organism samples and biofilm, respectively. The number of isolates varied for each sample (Table 2). The highest number of EP (15 isolates) was isolated from Caulerpa racemosa (PD4), whilst the lowest number of isolates (5 isolates each) was obtained from Sargassum sp. (PD1) and Silunaria sp. (PD2). Most of the isolates showed colonies' characteristics that were translucent and opaque in opacity; circular, oval and irregular in form; flat and slightly raise in elevation; entire and undulate in margin; and shine or course surfaces. Additionally, the dominant colours were cream (92 isolates), followed by yellow (11 isolates), orange (6 isolates), brown (1 isolate) and off-white (2 isolates). 
Table 2. The number of isolates from each sample

\begin{tabular}{lc}
\hline Samples & No. of isolates \\
\hline PJ3 Cladophora glomerata & 12 \\
PJ5 Acantophora spicifera & 10 \\
PJ6 Glacilaria edulis & 8 \\
PD1 Sargassum sp. & 5 \\
PD2 Silunaria sp. & 5 \\
PD3 Galaxea sp. & 8 \\
PD4 Caulerpa racemosa & 16 \\
PD5 Sarcophyton sp. & 3 \\
PD6 Seriatopora hystrix & 10 \\
PD7 Caulerpa sp. & 6 \\
PK8 Porites sp. & 8 \\
Biofilm from fish net & 21 \\
\hline
\end{tabular}

In this study, different macroalgae, soft and hard corals with clean surfaces were selected as the source of epiphytic bacteria, with the proposition that their intact surfaces were maintained by their host-associated bacteria. Some epiphytic bacteria play the protective role to the host by emitting inhibitory compounds to the surrounding, preventing the attachment of invaders and subsequent biofouling (Radjasa et al., 2004; Marhaeni et al., 2011). In addition, a random selection of the macroorganism' sources from different intertidal zones was carried out in order to acquire various communities of epiphytic bacteria, so that the best isolate with the greatest antifouling activity could be attained.

\section{Preliminary screening}

From the cross-streak assay, 55 isolates from the $91 \mathrm{EP}$ were found to be able to inhibit 10 or more FB $(\geq 50 \%)$. During the second test, some of them showed inconsistency in the inhibitory activity. Therefore, we decided to select the EPs that were capable of inhibiting 8 or more FB $(\geq 40 \%)$ in both replicates before proceeding to the secondary screening. The percentage of EP that qualified this requirement was $40.66 \%$ (37 EP). Figure 1 shows the number of EP that exhibited $\geq 50 \%$ (replicate 1 ) and $\geq 40 \%$ (replicate 2 ) of inhibitions when tested against the 21 FB. From the graph, all samples show reduction in their inhibitory activity, except for PJ6 that remain the same. Epiphytic bacteria of PD2 and PD3 were incapable of inhibiting the growth of eight 
or more than $8 \mathrm{FB}(\geq 40 \%)$. The fuzzy and indistinct FB colonies displayed by FB7 and FB13 in Figure 2 (a) suggest that their growths were distorted due to the inhibitory effect secreted by the EP PD4.8. Meanwhile, no inhibitory activity was produced by EP PD4.9 against tested FB as illustrated in Figure 2 (b).

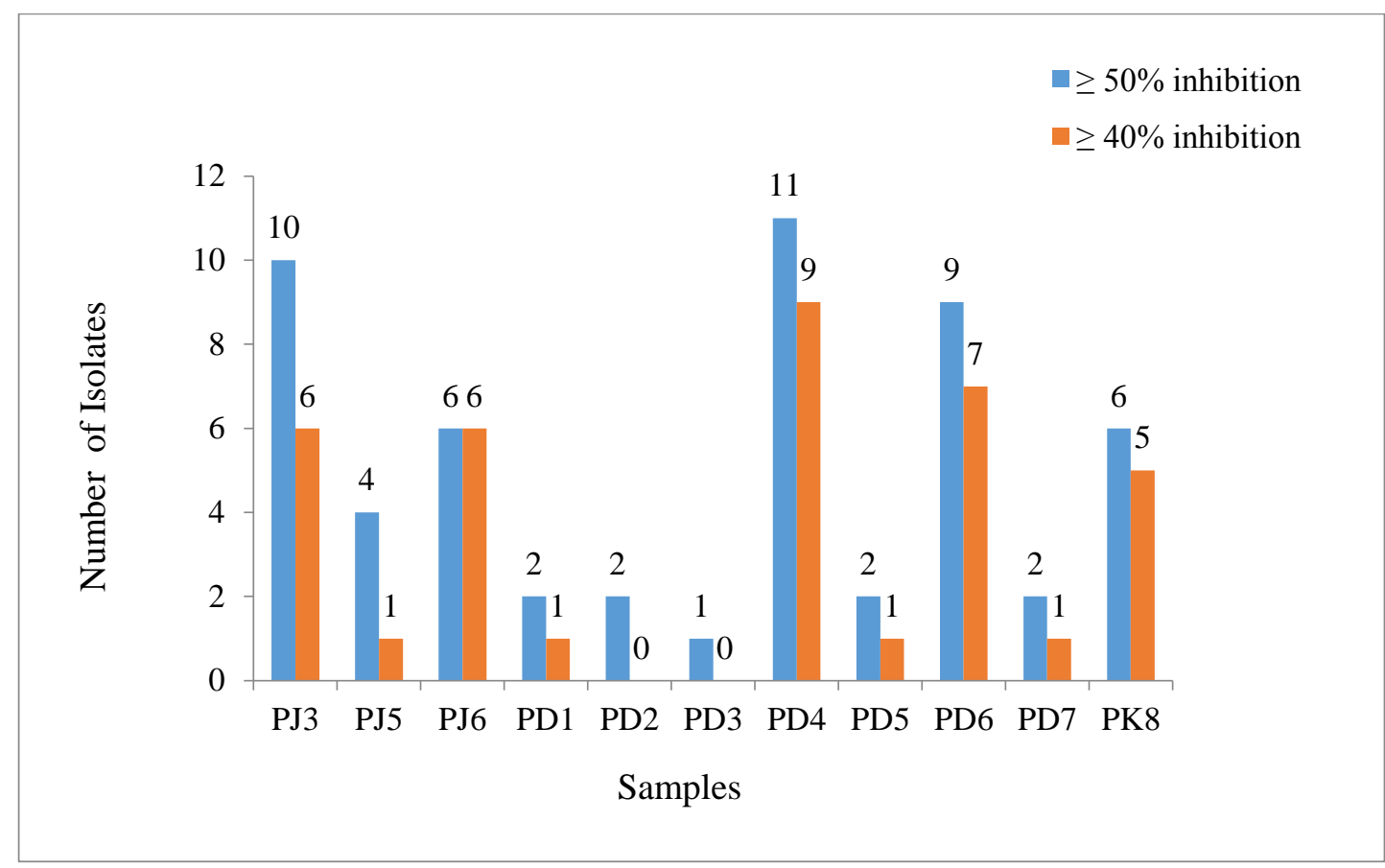

Figure 1. The number of epiphytic bacteria from each sample that showed $\geq 50 \%$ of inhibition (susceptible FB is $\geq 10$ ) and $\geq 40 \%$ of inhibition (susceptible FB is $\geq 8$ ) against the fouling bacteria.
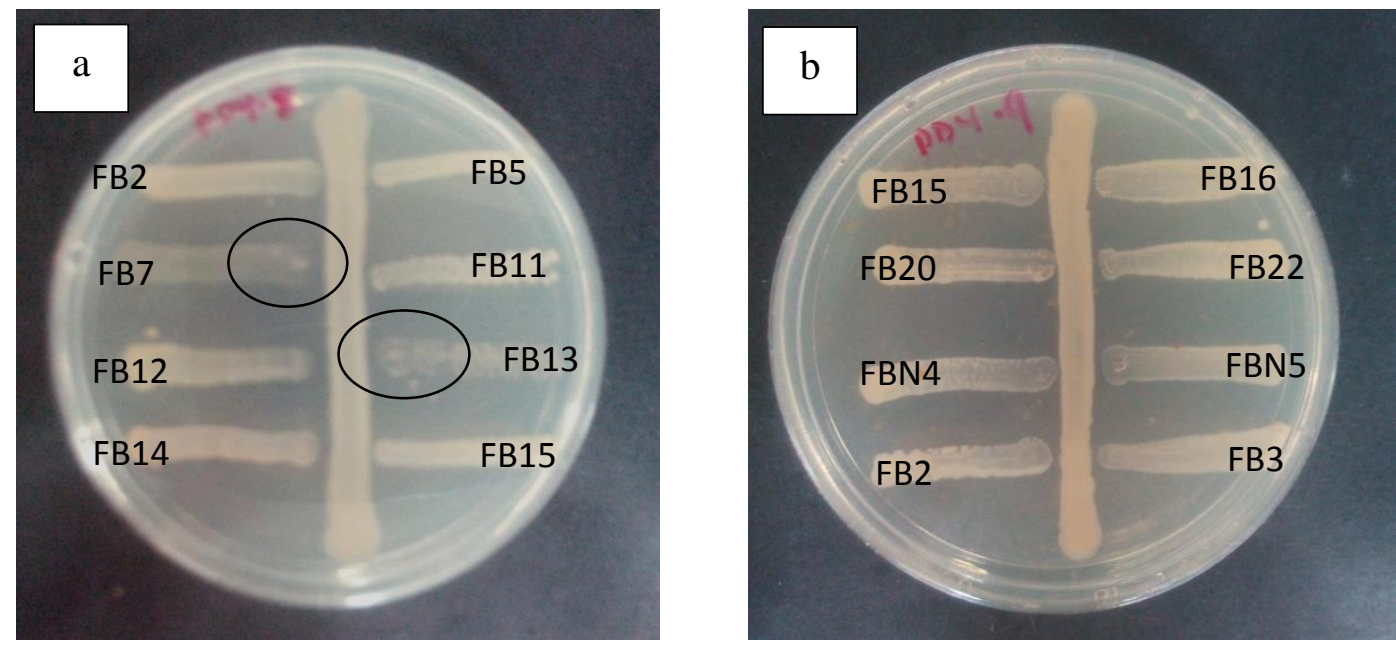

Figure 2. The cross-streak results for two epiphytic bacteria against tested fouling bacteria. Figure 2a shows the suscpetible fouling bacteria of FB3 and FB9 (circled areas) when acted with isolate PD4.8 and Figure $2 \mathrm{~b}$ shows the unaffected fouling bacteria when acted with isolate PD4.9. 
The cross-streak assay demonstrates the antagonistic interactions between the epiphytic bacteria and fouling bacteria. The repellent property of the secondary metabolites of the epiphytic bacteria is used to prevent the colonization of other prokaryotes and eukaryotes competitors (Rao et al., 2007). The 4-days period allocated for the EP to grow was adequate to release the chemoeffectors into the agar media prior to encountering them with the FB. These chemoeffectors would produce negative chemotaxis that caused the FB to move away along the concentrations gradients of the chemoeffectors. The differences in FB susceptibility degrees towards the EP might be due to the different secondary metabolites they produced (Nithyanand et al., 2010; Abu Sayem et al., 2011). Some of them are capable of excreting diverse secondary metabolites that lead to the broad-spectrum antimicrobial activity while others might produce narrow spectrum and specific metabolites that are active against a selected group of bacteria. This theory is concurrent with the results obtained in the present study that showed variability in the number of susceptible FB of different EP.

In the primary screening we only selected the EP that was capable of inhibiting 8 or more FB $(\geq 40 \%)$ before proceeding to the secondary screening. This is because, we hypothesized that each of the isolated FB plays a role in the subsequent attachment and germination of Enteromorpha sp. zoospores and thalli, and the more the number of FB that can be inhibited indicates higher chances to prevent the biofouling. In a natural biofilm, the intra- and interspecies interactions between the bacteria enhance the settlement of invertebrates' larvae and spores (Rao et al., 2007; Qian et al., 2007). It is also suggestive that higher bacterial density will develop more nutrient-rich biofilm which is more attractive to the zoospores and larvae. This criteria is supported by a finding that demonstrated the number of Enteromorpha zoospores that attached to the glass slides (initially developed with biofilms) were in parallel with the number of bacteria present in the biofilm (Joint et al., 2000). The bacteria used to develop the biofilm were isolated from the sampling site for Enteromorpha thalli, validating that those bacteria were responsible to induce biofouling of Enteromorpha sp. in the region. Therefore, in this study only the EPs that showed inhibition of more than $40 \%$ of the fouling bacteria were continued with the secondary screening as we aimed to search for EP that could inhibit more FBs. 


\section{Secondary screening}

Thirty out of 36 isolates were selected for secondary screening. The remaining six isolates were uncultivable prior to the test. Of the 30 extracts, 12 of them displayed positive antibacterial activities at $2.0 \mathrm{mg} /$ disc. The size of inhibition zones varied among the extracts and FB. Table 3 summarizes the antibacterial activity for the 30 extracts, with the strongest antibacterial activity demonstrated by the extract from $C$. racemosa (PD4). Amongst the seven isolates of PD4, isolate PD4.8 appeared as the most potential $t$ isolate with inhibition of five out of nine tested $\mathrm{FB}$, with size of inhibition zones from 9.0 to $16.0 \mathrm{~mm}$ (data not shown). The second significant isolate was PD4.9 which inhibited four out of ten tested fouling bacteria FB?, with inhibition zones ranging from 8.5 to 15.0 mm. The extracts of PJ3, PJ5, PD5, PD7 and PK8 possessed no inhibitory activity to any of the tested fouling bacteria. The negative control (methanol) produced no inhibition zone against all tested FB. All FB were susceptible to the positive control copper omadine $(\mathrm{CO})$ at $0.002 \mathrm{mg} /$ disc. Figure 3 shows the inhibition zones produced by one of the PD4 extracts.

Table 3. Antibacterial activity of ethyl acetate extracts of different epiphytic isolates against fouling bacteria

\begin{tabular}{ccccc}
\hline Sample & Isolates & $\begin{array}{c}\text { No. of FB } \\
\text { tested }^{\mathrm{a}}\end{array}$ & $\begin{array}{c}\text { No. of susceptible } \\
\text { FB }\end{array}$ & $\begin{array}{c}\text { Range of inhibition zones } \\
(\mathrm{mm})\end{array}$ \\
\hline PJ3 & PJ3.7 & 9 & 0 & - \\
& PJ3.8 & 11 & 0 & - \\
& PJ3.9 & 9 & 0 & - \\
& PJ3.12 & 11 & 0 & - \\
& PJ3.13 & 11 & 0 & - \\
\hline PJ5 & PJ5.8 & 10 & 0 & - \\
& & & & $7.0-9.0$ \\
\hline PJ6 & PJ6.2 & 14 & 2 & $8.0-9.0$ \\
& PJ6.7 & 11 & 1 & - \\
& PJ6.9 & 13 & 0 & $8.0-9.0$ \\
& PJ6.10 & 10 & 1 & Partial \\
& & & & $8.0-9.0$ \\
\hline PD1 & PD1.2 & 11 & 1 & partial \\
& & & 2 & $9.0-16.0$ \\
\hline PD4 & PD4.6 & 16 & 1 & $8.5-15.0$ \\
& PD4.7 & 10 & 5 & \\
& PD4.8 & 9 & 4 & \\
\hline
\end{tabular}




\begin{tabular}{ccccc}
\hline & PD4.12 & 9 & 1 & 13.0 \\
& PD4.13 & 18 & 0 & - \\
\hline PD5 & PD5.5 & 8 & 0 & - \\
& & & & - \\
\hline PD6 & PD6.3 & 13 & 0 & - \\
& PD6.4 & 13 & 0 & $10.0-12.0$ \\
& PD6.5 & 15 & 1 & - \\
& PD6.7 & 11 & 0 & partial \\
& PD6.9 & 16 & 2 & $10.0-11.0$ \\
& PD6.11 & 16 & 1 & - \\
\hline PD7 & PD7.11 & 15 & 0 & - \\
& & & & - \\
\hline PK8 & PK8.4 & 9 & 0 & - \\
& PK8.7 & 11 & 0 & - \\
& PK8.9 & 10 & 0 & - \\
& PK8.11 & 9 & 0 & - \\
& PK8.12 & 8 & 0 & \\
& & & & \\
\hline
\end{tabular}

FB- fouling bacteria; no. of tested $\mathrm{FB}^{\mathrm{a}}$ based on the preliminary screening; - : indicates no result.

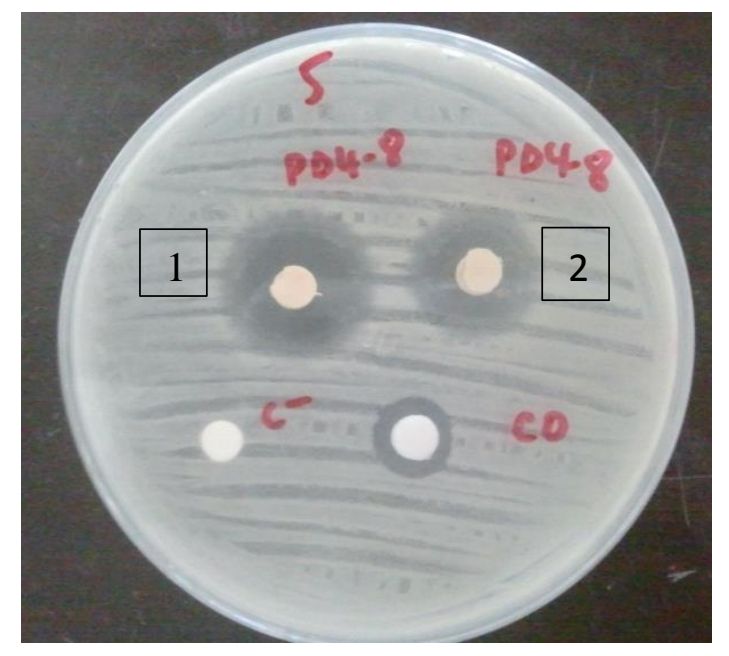

Figure 3. The inhibition zones produced by the ethyl acetate extract of isolate PD4.8 against fouling bacteria FB7 were displayed by the clear zones (1 and 2). The $\mathrm{CO}$ and $\mathrm{C}^{-}$represent the positive (copper omadine) and negative (methanol) controls, respectively. 
In the extraction process, only the free-cell supernatant was extracted with ethyl acetate to obtain the extracellular compounds. This is the continuity from the cross-streak test that proved the existence and action of extracellular compounds against the FB. Secondary metabolites were originally produced within the epiphytic cells and slowly excreted to the ecosystem to execute their functions (Armstrong et al., 2001). Many different secondary metabolites with antimicrobial property have also been isolated from marine epiphytes (Kanagasabhapathy et al., 2006; Nithyanand et al., 2010; Abu Sayem et al., 2011).

The results also showed that some extracts (PJ3, PJ5, PD5, PD7 and PK8) did not display any inhibitory activity against the tested FBs. The loss of antimicrobial activity might be due to the types of compounds that exist in the supernatant, which was also influenced by the types of organic solvent used during the liquidliquid extraction method. Ethyl acetate was selected for the extraction due to its immiscibility and medium polarity properties, and also its capability to extract the medium and non-polar compounds from the supernatant (Khandhasamy \& Arunachalam, 2008). Secondly, the medium (solid or liquid) used to produce the bioactive compounds is also important.
During the primary screening, the EPs were grown on solid medium. However, the medium was changed to liquid form of MB. Some EP might only be capable of producing their secondary metabolites when they are bound to the substratum. A study has found that the surface-bound bacteria that were grown as biofilm was significantly less favored by the bacterivorous flagellate Rhynchomonas nasuta as their food source, in comparison to the planktonic bacteria (Matz et al., 2008). The result indicated that the surface-bound bacteria were active in discharging toxic compounds to the surroundings and became resistant to the feeder. Additionally, the secondary metabolites might get lost in axenic culture and sometimes could be restored by reinfection with the FB invaders.

A number of studies have focused on the antifouling activities of macroalgae and sponges extracts against the green fouling alga Enteromorpha sp. and Ulva sp. (Cho et al., 2001; Hellio et al., 2002). However, due to the inadequate supplies of the natural sources together with financial and production disadvantages, marine microorganisms have been the new focus of attention. The first advantage of using microorganisms is it is a sustainable source, and the production of the microbial secondary metabolites can be reproduced 
in a large scale via fermentation. Secondly, it has been suggested that marine microbes are the producers of a rich number of bioactive compounds due to their extreme habitat (Debbab et al., 2010).

Diketopiperazines, a compound from the epiphytic bacteria Pseudoalteromonas sp. Isolated from sponge, has been demonstrated to possess antimicrobial activity against a wide range of microbes (Martínez-Luis et al., 2011). Additionally, the extract of a bacteria isolated from the surface of nudibranch Archidoris pseudoargus also revealed a pronounced effect in inhibiting the fouling bacteria (Armstrong et al., 2000). In biofouling process, the initial attachment of fouling bacteria on the submerged surface is followed with the development of biofilm and attachment of algal zoospores. Therefore, the results from this study suggest that, the epiphytic isolates which possess the antibiofilm antibacterial property against fouling bacteria could prevent the attachment of algal zoospores. For instance, a highly potential tambjamines compound and an unknown purple pigment that were isolated from $P$. tunicata (tunicate) and $P$. ulva (Ulva sp.), respectively have displayed antifouling activity against the fouling bacteria, biofilm, algal spores, and invertebrate larvae (Egan et al., 2001; Franks et al., 2005).

In this study, the most active epiphytic isolates which are PD4.8 and PD4.9 were originated from the surface of macroalgae Caulerpa racemosa. The epiphytes of Caulerpa species have been studied elsewhere before, but no significant results have been obtained. An analysis on the bioactivities possessed by different species of epiphytic bacteria isolated from the green, red, and brown macroalgae from various references showed that no record has been found regarding the bioactivities of epiphytic bacteria from the genus Caulerpa (El Bour et al., 2013). Likewise, a study on the epiphytic bacteria and fungi associated with $C$. racemosa of Kenyan coastal region also illustrated no specific result on the antimicrobial activity against the pathogenic microbes (Kaaria et al., 2015). In a different work, the supernatant of the epiphytic bacteria of $C$. racemosa from Takalar Coast, South Sulawesi displayed strong antibacterial and antifungal activities against pathogenic bacteria and yeast (Sartini et al., 2012). However, the study did not evaluate the organic extract of the epiphytic bacteria, unlike the present study that used ethyl acetate to extract the secondary compounds. 


\section{CONCLUSIONS}

As for the conclusion, a total of 91 epiphytic bacteria were isolated from eleven marine organisms with 37 of them showing positive inhibitory activity against the fouling bacteria, during the preliminary screening. In the secondary screening, 13 out of 37 ethyl acetate extracts of the isolates exhibited antimicrobial activities. Amongst them, two highly potential epiphytes bacteria which were PD4.8 and PD4.9, isolated from the surface of $C$. racemosa were found to possess significant inhibitory property against a number of fouling bacteria. Further studies are required to isolate, purify and identify the bioactive compounds from the crude extracts.

\section{ACKNOWLEDGEMENT}

This work was supported by the Universiti Sains Malaysia Research Grant (grant no. 1001/PBIOLOGI/815098). The samples were identified by Associate Prof Dr. Ahmad Ismail of Universiti Kebangsaan Malaysia, Malaysia and Mohamad Saupi Ismail of the Fisheries Research Institute, Batu Maung, Penang, Malaysia.

\section{REFERENCES}

Abu Sayem SM., Manzo E., Ciavatta L., Tramice A., Cordone A., Zanfardino A., De Felice M. \& Varcamonti M. (2011). Anti-biofilm activity of an exopolysaccharide from a spongeassociated strain of Bacillus licheniformis. Microbial.Cell Factories.10: 74.

Armstrong E., Boyd KG. \& Burgess, JG. (2000). Prevention of marine biofouling using natural compounds from marine organisms. Biotechnology Annual Review 6: 221-241.

Armstrong E., Yan L., Boyd KG., Wright PC. \& Burgess, JG. (2001). The symbiotic role of marine microbes on living surfaces. Hydrobiologia 461: $37-40$.

Bayva M., Mohanapriya P., Pazhanimurugan R. \& Balagurunathan, R. (2011). Potential bioactive compound from marine actinomycetes against biofouling bacteria. Indian Journal of GeoMarine Sciences 40: 578-582.

Bazes A., Silkina A., Defer D., Bernède C., Quéméner E., Braud JP. \& Bourgougnon, N. (2006). Active substances from Ceramium botrycarpum used as antifouling 
products in aquaculture. Aquaculture 258: 664-674.

Burgess JG., Boyd KG., Armstrong E., Jiang Z., Yan L., Berggren M., May U., Pisacane T., Granmo A. \& Adams, DR. (2003). The development of a marine natural product-based antifouling paint. Biofouling. 19: 197-205.

Cho JY., Kwon E-H., Choi J-S., Hong SY., Shin H-W. \& Hong, YK. (2001). Antifouling activity of seaweed extracts on the green alga Enteromorpha prolifera and the mussel Mytilus edulis. Journal of Applied Phycology 13: 117-125.

Debbab A., Aly AH., Lin, WH. \& Proksch, P. (2010). Bioactive compounds from marine bacteria and fungi. Microbial Biotechnology 3: 544-563.

Devi P., Wahidullah S., Rodrigues C. \& Souza, LD. (2010). The spongeassociated bacterium Bacillus licheniformis SAB1: A source of antimicrobial compounds. Marine Drugs 8: 1203-1212.

Dobretsov S., Teplitski M. \& Paul, V. (2009). Mini-review: quorum sensing in the marine environment and its relationship to biofouling. Biofouling 25: 413- 427.
Egan S., Holmstrom C. \& Kjelleberg, S. (2001). Pseudoalteromonas ulvae sp. nov., a bacterium with antifouling activities isolated from the surface of a marine alga. International Journal of Systematic and Evolutionary Microbiology 51: 1499-1504.

El Bour M., Ahmad Ismail A. \& Ktari L. (2013). Microbial Pathogens and Strategies for combating them: Science, Technology and Education, pp. 1298-1306, Spain: Formatex Research Center.

Fletcher RL. \& Callow, ME. (1992). The settlement, attachment and establishment of marine algal spores. British Phycological Journal 27: 303-329

Franks A., Haywood P., Holmström C., Egan S., Kjelleberg S. \& Kumar N. (2005). Isolation and structure elucidation of a novel yellow pigment from the marine bacterium Pseudoalteromonas tunicata. Molecules 10: 1286-1291.

Hellio C., Berge JP., Beaupoil C., Le Gal Y. \& Bourgougnon, N. (2002). Screening of marine algal extracts for anti-settlement activities again microalgae and macroalgae, Biofouling 18: 205-215.

Hill JE., Baiano JCF. \& Barnes, AC. (2009). Isolation of a novel strain 
Bacillus pumilus from penaeid shrimp that is inhibitory against marine pathogens. Journal of Fish Diseases 32: 1007-1016.

Iwata H., Tanabe S., Mizuno T. \& Tatsukawa, R. (1995). High accumulation of toxic butyltins in marine mammals from Japanese coastal waters. Environmental Science and Technology 29: 29592962.

Jiang P., Li J., Han F., Duan G., lu X., Gu Y. \& Yu, W. (2011). Antibiofilm activity of an exoploysaccharide from marine bacterium Vibrio sp. QY101. PLoS ONE 6(4): e18514.

Joint I., Callow EM., Callow JA. \& Clarke, KR. (2000). The attachment of Enteromorpha zoospores to a bacterial biofilm assemblage. Biofouling. 16: 151-158.

Kaaria P., Matiru V., Wakibia J., Bii C. \& Ndung, M. (2015). Antimicrobial activity of marine algae associated endophytes and epiphytes from the Kenya Coast. International Journal of Current Microbiology and Applied Sciences 4: 17-22.

Kanagasabhapathy M., Sasaki H., Soumya H., Yamasaki S. \& Nagata, S. (2006). Antibacterial activities of marine epibiotic bacteria isolated from brown algae of Japan. Annual Microbiology 56: 167-173.

Khandhasamy M. \& Arunachalam, KD. (2008). Evaluation of in vitro antibacterial property of seaweeds of southern coast of India African Journal of Biotechnology 7: 19581961.

Lai HC., Kessler AO. \& Khoo, LE. (1993). Biofouling and its possible modes of control at fish farms in Penang, Malaysia. Asian Fisheries Science 6: 93-116.

Lappin-Scott HM. \& Costerton, JW. (1989). Bacterial biofilms and surface fouling. Biofouling 1: 323342.

Limna Mol VP., Raveendran TV. \& Parameswaran, PS. (2009). Antifouling activity exhibited by secondary metabolites of the marine sponge, Haliclona exigua (Kirkpatrick). International Biodeteroriation and Biodegradation 63: 67-72.

Madin J., Chong VC. \& Badrulnizam, B. (2009). Development and short-term dynamics of macrofouling assemblages of fish-cage nettings in a tropical estuary. Estuarine, Coastal and Shelf Science 83: 19-29.

Marhaeni B., Radjasa OK., Khoeri MM., Sabdono A., Bengen DG. \& Sudoyo, 
H. (2011). Antifouling activity of bacterial symbionts of seagrasses against marine biofilm-forming bacteria. Journal of Environmental Protection 2: 1245-1249.

Martínez-Luis S., Ballesteros J. \& Gutiérrez, M. (2011). Antibacterial constituents from the octoralassociated bacterium

Pseudoalteromonas sp. Revista Latinoamericana de Química, 39: 75-83.

Martínez-Luis S., Ballesteros J. \& Gutiérrez, M. (2011). Antibacterial constituents from the octoralassociated bacterium

Pseudoalteromonas sp. Revista Latinoamericana de Química, 39: 75-83.

Matz C., Webb JS., Schupp PJ., Phang SY., Penesyan A., Egan S., Steinberg P. \& Kjelleberg, S. (2008). Marine biofilm bacteria evade eukaryotic predation by targeted chemical defense. PLOS ONE 3: e2744.

McCloskey J. (2003). Salmon pens, green slime and clams. :http://www.epbea.org/article05.htm (accessed January 10, 2015).

Nor Afifah S., Darah I., Shaida FS., Mohd Jain Nordin MK. \& Nurul Aili, Z. (2010). Antimicrobial activity of various extracts of a tropical
Chlorophyta Macroalgae, Halimeda discoidea. Journal of Applied Sciences 10: 3007-3013.

Nithyanand P., Thenmozhi R., Rathna J. \& Pandian, SK. (2010). Inhibition of Streptococcus pyogenes biofilm formation by coral-associated actinomycetes, Current. Microbiology 60: 454-460.

Patel P., Callow ME., Joint I. \& Callow, JA. (2003). Specificity in the settlement-modifying response of bacterial biofilms towards zoospores of the marine alga Enteromorpha. Environmental Microbiology 5: 338349.

Pereira MO., Kuehn M., Wuertz S., Neu T. \& Melo, L. (2002). Effect of flow regime on the architecture of a Pseudomonas fluorescens biofilm. Biotechnology and Bioengineering 78: $164-171$.

Qian P-Y., Lau SCK., Dahms HU., Dobrestov S. \& Harder, T. (2007). Marine biofilms as mediators of colonization by marine macroorganisms: implications for antifouling and aquaculture. Marine Biotechnology 9: 399-410.

Radjasa OK., Marten T, Brinkoff T, Grossart H.-P., Sabdono A. \& Simon, M. (2004). Antibacterial activity of a secondary metabolite- 
producing coral bacterium Pseudoalteromonas species. Journal of Coastal Development 7: 79-88.

Rao D., Webb JS., Hölmstrom C., Case R., Low A., Steinberg P. \& Kjelleberg. S. (2007). Low densities of epiphytic bacteria from the marine algae Ulva australis inhibit settlement of fouling organisms. Applied and Environmental Microbiology 73: 7844-7852.

Sartini, Suryadi, Nur Afni \& Ayu Permata, S. (2012). Isolation Bacterial
Symbiont from Ulva reticulate and Caulerpa racemosa as candidate of antimicrobial producer. Proceedings of the Wallace Darwin Science Symposium, Makassar, Indonesia.

Velho-Pereira S. \& Kamat, NM. (2011). Screening of actinobacteria for antimicrobial activities by a modified "Cross-Streak" method. Indian Journal of Pharmaceutical Sciences 73: 223-228. 